\title{
Isolates of Uromyces appendiculatus with Specific Virulence to Landraces of Phaseolus vulgaris of Andean Origin
}

\author{
Craig M. Sandlin, James R. Steadman, and Carlos M. Araya, Department of Plant Pathology; and Dermot P. \\ Coyne, Department of Horticulture, University of Nebraska, Lincoln 68583
}

\begin{abstract}
Sandlin, C. M., Steadman, J. R., Araya, C. M., and Coyne, D. P. 1999. Isolates of Uromyces appendiculatus with specific virulence to landraces of Phaseolus vulgaris of Andean origin. Plant Dis. 83:108-113.

Five isolates of the bean rust fungus Uromyces appendiculatus were shown to be specifically virulent on bean genotypes of Andean origin. This specificity was demonstrated by the virulence of five pairs of isolates on a differential set of 30 Phaseolus vulgaris landraces. Each isolate pair was from a different country in the Americas and consisted of one Andean-specific isolate and one nonspecific isolate. Of the differential P. vulgaris landraces, 15 were of Middle American origin and 15 were of Andean origin. The Andean-specific rust isolates were highly virulent on Andean landraces but not on landraces of Middle American origin. Rust isolates with virulence to Middle American landraces were also generally virulent on Andean material; no truly Middle American-specific isolates were found. Random amplified polymorphic DNA (RAPD) analysis of the rust isolates also distinguished the two groups. Four of the Andeanspecific rust isolates formed a distinct group compared to four of the nonspecific isolates. Two of the isolates, one from each of the two virulence groups, had intermediate RAPD banding patterns, suggesting that plasmagomy but not karyogamy occurred between isolates of the two groups.
\end{abstract}

Pathotype diversity has been characterized for several plant pathogens, including Uromyces appendiculatus (Pers.:Pers.) Unger, the causal agent of bean rust. $U$. appendiculatus is a highly variable pathogen, with more than 300 races reported (24). This pathogenic diversity, combined with a well-characterized, agronomically important host plant, provides an excellent pathosystem for the study of specific virulence.

Domesticated common bean (Phaseolus vulgaris L.) occurs in two major gene pools, Andean and Middle American $(6,21)$. The two forms are believed to have been independently domesticated in preColumbian times from biologically and geographically distinct wild populations. The Andean form originated in the Andean region of South America, while the Middle American form was domesticated from wild populations in Mexico and Central America. Three Andean races and three

Corresponding author: C. M. Sandlin

E-mail: craig.sandlin@ seeds.novartis.com

Research conducted under Title XII Bean/Cowpea CRSP project UN/UPR/DR, USAID contract DAN-1310-G-SS-6008-00 and UN project 21-049. Published as Journal Series 11765 Agricultural Research Division, University of Nebraska.

Accepted for publication 17 September 1998.

Publication no. D-1998-1130-06R

(C) 1999 The American Phytopathological Society
Middle American races of $P$. vulgaris were originally described based on morphological and biochemical criteria (21). The separation of Andean and Middle American forms has been reconfirmed using various molecular markers $(4,7,10)$.

Differential host genotypes are commonly used to distinguish races of rust pathogens. Since 1983, a set of 19 standard bean rust differential lines or cultivars (Table 1) has been used to distinguish races and pathotypes of $U$. appendiculatus (23). Using these standard differentials, numerous races of the pathogen from the United States $(3,25)$ and other countries throughout the world $(1,16,17,20)$ have been defined. Little is known, however, about the origins of the standard differentials. Several are selections from relatively uncharacterized landraces, while other lines or cultivars were developed in early breeding programs. Analysis of phaseolin type and morphological traits (20), as well as molecular analysis (sequence characterized amplified regions [SCARs]; W. C. Johnson, personal communication), indicates that some of the differentials are of mixed Andean and Middle American backgrounds (Table 1).

The existence of Andean-specific pathotypes of $U$. appendiculatus was suggested by studies of a pathotype which had caused an epidemic on a newly released dry bean cultivar, PC-50, in the Dominican Republic (20). PC-50 was developed from Andean landraces traditionally grown in the Dominican Republic. The pathotype was highly virulent on several Andean landraces and on most of the standard bean rust differentials thought to be of Andean origin, but was avirulent or caused only small uredinia on the Middle American differentials. However, the interpretation of these results was complicated by the lack of knowledge concerning the origin of some of the standard bean rust differentials.

In recent years, molecular tools have been employed to characterize pathogen variability. Random amplified polymorphic DNA (RAPD) analysis, a polymerase chain reaction (PCR)-based molecular technique, has been used to characterize several pathosystems $(8,9,11,14,19)$.

The objective of this study was to determine if some pathotypes of $U$. appendiculatus are specifically virulent on beans of Andean or Middle American origin. To better characterize Andean and Middle American specificity, a second set of differentials was created using Andean and Middle American bean landraces. Both landrace differentials and the standard differentials were used to investigate the pathogenic specificity of ten isolates of $U$. appendiculatus. The genetic backgrounds of the isolates were also compared using RAPD analysis.

\section{MATERIALS AND METHODS}

Bean genotypes. Two sets of bean genotypes were used to characterize rust isolates: the 19 standard bean rust differentials and a set of 30 landrace differentials. The standard bean rust differentials were selected at the 1983 International Bean Rust Workshop (23) to define races of $U$. appendiculatus throughout the world. The 30 landraces used as a second set of differentials were provided by $\mathrm{S}$. Singh (CIAT, Cali, Colombia). Some of those landraces had been used previously in the studies which originally define the six races of domesticated $P$. vulgaris (21). The set included five landraces from each of the six races of domesticated $P$. vulgaris. Middle American landraces were: Carioca, Porrillo Sintético, Brasil 2, Orgulloso, Rio Tibagi (race Mesoamerica); Durango 222, Zacatecano, Ojo de Cabra Santa Rita, Guanajuato 31, Dilnason (race Durango); and Frijola, Garbancillo Zarco, Flor de Mayo IV, Amarillo 154 Cejita (race Jalisco). The Andean landraces were: Jatu Rong, Ecuador 1056, Jalo EEP 558, Radical San Gil, Alubia 
Cerrillos (race Nueva Granada); Frutilla Corriente, Coscorrón Corriente, Tortolas Corriente, Blanco Español, Burros Argentinos (race Chile); and Mortiño, Caballero, Nuña Maní Roja, Bolón Rojo, Bolón Bayo (race Peru).

Rust isolates. A total of 10 isolates of $U$. appendiculatus were characterized in this study. Races 38 and 54 (22) were provided by J. R. Stavely (United States Department of Agriculture, Beltsville, MD). The other eight isolates were from a bean rust collection at the University of $\mathrm{Ne}$ braska, Lincoln. The isolates were selected as pairs, each from a different country in the Americas: the United States, Honduras, Argentina, Jamaica, and the Dominican Republic. The pairs consisted of one apparently Andean-specific isolate (as determined from pathogenicity and virulence on the standard bean rust differentials), and one isolate with virulence on Middle American germplasm. Each isolate was cultured from a single uredinium and increased on an appropriate susceptible genotype in cloth isolation chambers in a greenhouse. All isolates were checked for purity by reinoculation onto the standard bean rust differentials.

Inoculation and disease evaluation. The procedure used to inoculate seedlings was based on that described by Stavely (22). Urediniospore inoculum was prepared by suspending $2.5 \mathrm{mg}$ of either fresh or frozen spores in $75 \mathrm{ml}$ of a Tween-20 solution $(40 \mu \mathrm{l} / \mathrm{liter})$. The spore suspensions were spray-inoculated onto immature (not fully expanded) primary leaves of bean seedlings. Both abaxial and adaxial leaf surfaces were sprayed to runoff. The inoculated plants were allowed to dry and were then placed into a mist chamber $(100 \%$ relative humidity) for at least $14 \mathrm{~h}$ overnight at 20 to $22^{\circ} \mathrm{C}$. After misting, the plants were moved to greenhouse benches. Disease reactions were recorded 14 days after inoculation.

Disease symptoms were rated according to the scale adopted at the 1983 International Bean Rust Workshop (23), where 1 $=$ no symptoms; $2=$ necrotic flecks or spots without uredinia; $3=$ uredinia less than $300 \mu \mathrm{m}$ in diameter; $4=$ uredinia 300 to $499 \mu \mathrm{m}$ in diameter; $5=$ uredinia 500 to $799 \mu \mathrm{m}$ in diameter; and $6=$ uredinia 800 $\mu \mathrm{m}$ in diameter or larger. Only reaction grades are reported; uredinium density was monitored to ensure that it did not influence uredinium size.

RAPD analysis. DNA was extracted from germinated urediniospores. To germinate the urediniospores, 50-mg samples were exposed to the vapors of $\beta$-ionone for $30 \mathrm{~min}$, and then floated overnight on $5 \mathrm{ml}$ of germination buffer (16) to which the antibiotic rifampicin $(10 \mathrm{mg} / \mathrm{liter})$ was added to inhibit the growth of bacteria. The buffer was composed of $0.01 \mathrm{M}$ phosphate buffer ( $\mathrm{pH}$ 7.0) containing calcium phosphate $(2.5 \mathrm{mg} / \mathrm{liter})$, ethanol $(0.5 \mathrm{ml} / \mathrm{liter})$, Tween $20(0.1 \mathrm{ml} / \mathrm{liter})$, and $\beta$-ionone (5 $\mu \mathrm{l} /$ liter).

The germinated spores were frozen and ground in liquid nitrogen, and the resultant powder was suspended in $600 \mu \mathrm{l}$ of extraction buffer and incubated at $65^{\circ} \mathrm{C}$ for $1 \mathrm{~h}$. The extraction buffer contained potassium ethyl xanthagenate (100 g/liter), $\mathrm{NaCl}$ (81.8 g/liter), $200 \mathrm{ml}$ of $1 \mathrm{M}$ Tris buffer (pH 7.5) per liter, and $40 \mathrm{ml}$ of $0.5 \mathrm{M}$ EDTA per liter. After incubation, each sample was centrifuged for $10 \mathrm{~min}$ at
$16,000 \mathrm{rpm}$, and the supernatant was transferred to a clean microcentrifuge tube. Nucleic acids were then precipitated with a 6:1 mixture of ethanol and $7 \mathrm{M}$ ammonium acetate at $-20^{\circ} \mathrm{C}$. The precipitates were pelleted with a short spin in a microcentrifuge and washed with $70 \%$ ethanol. The precipitated DNA was purified using a commercial DNA extraction kit (Qiagen, Inc., Chatsworth, CA). The concentration of each sample was estimated spectrophotometrically and diluted to approximately $100 \mathrm{ng} / \mu \mathrm{l}$. The sample concentrations were then visually balanced after viewing electrophoresed samples stained with ethidium bromide. The samples were then diluted 10 -fold to give final concentrations of 10 ng of DNA/ $\mu$ l.

PCR was conducted in a $1600 \mathrm{X}$ airthermocycler (Idaho Technology, Inc., Idaho Falls, ID) in flame-sealed, 20- $\mu$ l glass capillary tubes. A $10-\mu \mathrm{l}$ sample of reaction mixture was used for each reaction. In addition to the sample DNA (20 ng), each reaction mixture contained 0.4 $\mu \mathrm{M}$ primer, $0.1 \mathrm{mM}$ DNTP, Taq polymerase $(0.5$ units $/ \mu \mathrm{l}), 2 \mathrm{mM} \mathrm{MgCl}_{2}, 50$ $\mathrm{mM}$ Tris (i.e., $2 \mu \mathrm{l}$ of $250 \mathrm{mM}$ Tris, $\mathrm{pH}$ 8.5 , per $10 \mu \mathrm{l}$ of reaction mixture), $20 \mathrm{mM}$ $\mathrm{KCl}, 0.5 \mu \mathrm{g} / \mu \mathrm{l}$ of bovine serum albumen, $2.5 \%$ ficoll 400 (vol/vol), and $0.02 \% \mathrm{xy}-$ lene cyanole (wt/vol). Two PCR regimes were used. The first regime consisted of two cycles of $60 \mathrm{sec}$ at $91^{\circ} \mathrm{C}, 7 \mathrm{sec}$ at $42^{\circ} \mathrm{C}$, and $70 \mathrm{sec}$ at $72^{\circ} \mathrm{C}$ followed by 38 cycles of $1 \mathrm{sec}$ at $91^{\circ} \mathrm{C}, 7 \mathrm{sec}$ at $42^{\circ} \mathrm{C}$, and $70 \mathrm{sec}$ at $72^{\circ} \mathrm{C}$, followed by a 4 -min hold at $72^{\circ} \mathrm{C}$. The second regime was the same as the first except that the annealing temperature for the second set of 38 cycles was $46^{\circ} \mathrm{C}$. All isolate-primer combinations

Table 1. Virulence ratings of five Andean-specific isolates and five nonspecific isolates of Uromyces appendiculatus on the 19 standard bean rust differential lines or cultivars ${ }^{\mathrm{a}}$

\begin{tabular}{|c|c|c|c|c|c|c|c|c|c|c|c|}
\hline \multirow[b]{2}{*}{ Differentials $^{c}$} & \multirow[b]{2}{*}{ Origin $^{d}$} & \multicolumn{5}{|c|}{ Andean-specific isolates ${ }^{b}$} & \multicolumn{5}{|c|}{ Nonspecific isolates $^{\mathbf{b}}$} \\
\hline & & ARG & DR & HON & JA & USA & ARG & DR & HON & $\mathbf{J A}$ & USA \\
\hline US 3 & $\mathrm{~A} / \mathrm{MA}$ & 4,5 & 3,4 & 3,2 & 4,3 & 3,4 & 4,5 & 5,6 & 5 & 5,6 & 5,4 \\
\hline CSW 643 & MA & 2 & 2 & 2 & 2 & 2 & 2 & 5,6 & 4,3 & $3,4,2$ & $2,3,4$ \\
\hline PINTO 650 & MA & 5,6 & 6,5 & 5,4 & 4,5 & $4,3,2$ & 5,6 & 5,6 & 5 & 5,6 & 6,5 \\
\hline KW 765 & A/MA & 2 & 1 & 2 & 2 & 2 & 2,3 & 5,6 & 5,4 & 4,3 & 5,4 \\
\hline KW 780 & A/MA & 4,3 & 4 & 3,4 & 3,2 & 4,3 & 2,3 & 2,3 & 2,3 & 5 & 2,3 \\
\hline KW 814 & MA & 1 & 1 & 1 & 1 & 1 & 5,4 & 5,6 & 5,4 & 3,4 & 5,6 \\
\hline G.G. Wax & A/MA & 5,6 & 5 & 5,4 & 4 & 5,4 & 5,6 & 5 & 5 & 5,4 & 5 \\
\hline Early Gallatin & A/MA & 6,5 & 5,6 & 5,6 & 6 & 6,5 & 2,3 & 2,3 & 2,3 & 5,4 & 2 \\
\hline Redlands Pioneer & A & 2 & 1 & 1 & 1 & 1 & 4,3 & 5 & 5,4 & 5 & 2,3 \\
\hline Equador 299 & MA & 1 & 1 & 1 & 1 & 1 & 2,3 & 2 & 5,4 & 4,5 & 2 \\
\hline Mexico 235 & MA & 1 & 1 & 1 & 1 & 1 & 1 & 2 & 5 & 4,3 & 2 \\
\hline Mexico 309 & A/MA & 1 & 1 & 2 & 1 & 1 & 3,2 & 3,4 & 5,4 & 5,4 & 4,3 \\
\hline Brown Beauty & A & 6,5 & 6 & 5,6 & 6,5 & 6 & 2,3 & 2,3 & 3 & 5 & 2,3 \\
\hline Olathe & MA & 2 & 2 & 2 & 2 & 2 & 3,4 & 5,6 & 5 & 5,4 & 4,5 \\
\hline AxS 37 & MA & 2 & 2 & 2 & 2 & 2 & 3,2 & 4,5 & 5 & 5,6 & 2,3 \\
\hline NEP-2 & MA & 2 & 2 & 2 & 2 & 2 & 3,4 & 2,3 & 4,3 & 4,3 & 2 \\
\hline Aurora & MA & $2,3,4$ & 1 & 2 & 2 & 2 & 5,6 & 2,3 & 5,4 & 5,6 & 2 \\
\hline 51051 & MA & 1 & 1 & 1 & 1 & 1 & 1 & 2 & 5 & 4 & 2,3 \\
\hline $\mathrm{CNC}$ & MA & 1 & 1 & 1 & 1 & 1 & 1 & 2 & 3,4 & 5,6 & 3,4 \\
\hline
\end{tabular}

a Virulence ratings: $1=$ no symptoms, $2=$ necrotic reaction without sporulation, $3=$ uredinia $<300 \mu \mathrm{m}$ in diameter, $4=$ uredinia 300 to $500 \mu \mathrm{m}$ in diameter, $5=$ uredinia 500 to $800 \mu \mathrm{m}$ in diameter, $6=$ uredinia $>800 \mu \mathrm{m}$ in diameter.

${ }^{\mathrm{b}}$ Geographic origin of isolates: ARG = Argentina, DR = Dominican Republic, HON = Honduras, JA = Jamaica, USA = United States of America.

${ }^{c}$ Standard bean rust differentials: CSW $=$ California Small White, KW = Kentucky, Wonder, G.G. Wax = Golden Gate Wax, CNC $=$ Compuesto Negro Chimaltenango.

${ }^{\mathrm{d}} \mathrm{A}=$ Andean, $\mathrm{MA}=$ Middle American, $\mathrm{A} / \mathrm{MA}=$ mixed. 
were run under both regimes; only banding patterns that were identical under both regimes were included in the numerical analysis. All isolate-primer combinations used in the analysis were run at least twice to ensure reproducibility. Oligonucleotides (Operon Technologies, Alameda, CA) of 10 base pairs were used as primers, and were selected based on their ability to detect one or more polymorphisms within the rust isolates used in the study. The manufacturer's primer designations and the sequences of the primers were: OPA-01 = CAGGCCCTTC, OPA-05 = AGGGGTCTTG, OPA-07 = GAAACGGGTG, OPA$10=$ GTGATCGCAG, OPA-11 = CAATCGCCGT, OPA-16 = AGCCAGCGAA, OPA-17 = GACCGCTTGT, OPB-11 = GTAGACCCGT, OPB-13 = TTCCCCCGCT, and OPB-18 = CCACAGCAGT. The 10- $\mu$ l samples were loaded directly into $1.5 \%$ agarose gels and electrophoresed at $106 \mathrm{mV}$ for $2 \mathrm{~h}$. The gels were stained for $10 \mathrm{~min}$ with ethidium bromide $(0.5$ $\mu \mathrm{g} / \mathrm{ml}$ ) and then destained for $15 \mathrm{~min}$ in deionized water.

Data from the RAPD analysis was subjected to parsimony analysis, which was conducted to recover similarity relationships of the banding patterns.

\section{RESULTS}

Inoculation on the standard bean rust differentials. Each of the 10 isolates was shown to be a distinct pathotype based on differential pathogenicity and virulence on the standard differentials; the Andean-specific isolates were more homogenous in their reactions on the differentials than were the non-specific isolates. The specificity of the Andean-specific isolates was indicated by their virulence on the differentials Kentucky Wonder 780, Early Gallatin, and Brown Beauty (Table 1). With the exception of the reactions on differential Pinto 650, the Andean-specific isolates were weakly virulent or nonpathogenic on the Middle American differentials. The virulence of the nonspecific isolates on the standard differentials showed neither Andean nor Middle American specificity.

Inoculation on Middle American and Andean landraces. The specificity of the Andean-specific isolates was more clearly demonstrated on the landrace differentials than on the standard differentials (Table 2). They were generally highly virulent on the Andean-specific landraces and only weakly virulent or avirulent on Middle American landraces. Only 5 of 75 combinations involving Andean-specific isolates on Mid- dle American landraces were able to infect and sporulate, and even then the uredinia were small $(<500 \mu \mathrm{m})$.

The five nonspecific isolates were generally virulent on both Andean and Middle American landraces (Table 2). However, the nonspecific isolate from Argentina was not as generally virulent on the Middle American landraces as the other four isolates.

RAPD analysis of the rust isolates. Using RAPD analysis, 50 polymorphisms were found using 10 random primers. Two primary banding patterns were observed (Fig. 1 and Table 3); of the 50 polymorphisms characterized, 21 of the polymorphisms formed the first pattern and 19 of the polymorphisms formed the second (Table 3). The remaining 10 banding patterns corresponded to one of the two primary patterns in that each could be formed by deletion of one or more bands from the corresponding primary pattern.

Based on the RAPD banding patterns, the 10 isolates can be divided into three groups: isolates whose banding patterns consist exclusively of bands associated with Andean-specific virulence (Andeanspecific isolates from Argentina, Honduras, Jamaica, and the United States); isolates whose banding patterns consist

Table 2. Virulence of five Andean-specific and five nonspecific isolates of Uromyces appendiculatus on Andean and Middle American landraces of Phaseolus vulgaris ${ }^{\mathrm{a}}$

\begin{tabular}{|c|c|c|c|c|c|c|c|c|c|c|}
\hline \multirow[b]{2}{*}{ Landraces $^{c}$} & \multicolumn{5}{|c|}{ Andean-specific isolates ${ }^{\mathbf{b}}$} & \multicolumn{5}{|c|}{ Nonspecific isolates ${ }^{b}$} \\
\hline & ARG & DR & HON & $\mathbf{J A}$ & USA & ARG & DR & HON & JA & USA \\
\hline \multicolumn{11}{|l|}{ Middle American } \\
\hline Carioca & 1 & 2 & 2 & 1 & 2 & 3 & 4,3 & 5,4 & 5,6 & 4,3 \\
\hline Porrillo Sintético & 2 & 1 & 1 & 2 & 1 & 3,4 & 4,3 & 5,4 & 3,2 & 5,6 \\
\hline Brasil 2 & $2, \overline{3}$ & 3 & 2 & 2 & 2 & 4,5 & 5,4 & 4,5 & 5,6 & 5,6 \\
\hline Orgulloso & 1 & 2 & 1 & 2 & 1 & 3 & 4,3 & 5,4 & 5 & 3,4 \\
\hline Rio Tibagi & 1 & 2 & 2 & 1 & 2 & 3 & 3,2 & 5 & 4,3 & 2 \\
\hline Durango 222 & 1 & 1 & 1 & 1 & 2 & 4,3 & 6,5 & 5,6 & 5,6 & 5,6 \\
\hline Zacatecano & 1 & 1 & 2 & 1 & 2 & 2 & 3,4 & 5,4 & 4,3 & 1 \\
\hline Ojo de Cabra & 2 & 1 & 1 & 1 & 2 & 2 & 3 & $5,4,3$ & 3,4 & 2,3 \\
\hline Guanajuato 31 & 2 & 2 & 1 & 2 & 2 & 2 & 4,5 & 3,4 & 4,3 & 2,3 \\
\hline Dilnason & 2,3 & 2,3 & 2 & 2 & 2 & 5,6 & 5,6 & 5,6 & 5,6 & 5,6 \\
\hline Frijola & 2 & 4,3 & 1 & 1 & 1 & 3,4 & 4,3 & 4,5 & 5,4 & 4,3 \\
\hline Garbancillo Zarco & 1 & 1 & 1 & 1 & 2 & 1 & 1 & 4,3 & 1 & 5,6 \\
\hline Flor de Mayo IV & 1 & 1 & 1 & 2 & 1 & 2 & 2,3 & 5,4 & 1 & 2 \\
\hline Amarillo 154 & 1 & 1 & 1 & 1 & 2 & 4 & 3,2 & 5,6 & 4,5 & 3 \\
\hline Cejita & 1 & 1 & 1 & 2 & 1 & 1 & 2,3 & 5,4 & 5,4 & 4,5 \\
\hline \multicolumn{11}{|l|}{ Andean } \\
\hline Jatu Rong & 5,6 & 5,6 & 5,6 & 6 & 5,6 & 5,6 & 5,6 & 5,6 & 5 & 4,5 \\
\hline Ecuador 1056 & 5,4 & 5 & 6,5 & 5,6 & 6,5 & 5 & 5,4 & 5,4 & 4,5 & 4,5 \\
\hline Jalo EEP 558 & 5,6 & 5,6 & 5,6 & 5,6 & 5,6 & 5,6 & 5 & 5,4 & 4,3 & 5 \\
\hline Radical San Gil & 5,6 & 5 & 1 & 3,4 & 1 & 5,6 & 5 & 5,4 & 5,4 & 4,5 \\
\hline Alubia Cerrillos & 6,5 & 5,6 & 1 & 1 & 1 & 6,5 & 5 & 5,4 & 5,4 & 4,5 \\
\hline Frutilla Corriente & 6,5 & 4,5 & 6,5 & 6,5 & 6,5 & 4,5 & $4,3,5$ & 2 & 4,3 & 4,3 \\
\hline Coscorrón Corriente & 5,6 & 5,6 & 6,5 & 5,6 & 5,6 & 5,6 & 5,4 & 4 & 5 & 5 \\
\hline Tortolas Corriente & 5,6 & 5 & 5,6 & 5,6 & 5,4 & 5,6 & 4,5 & 5 & 5,4 & 4,5 \\
\hline Blanco Español & 6,5 & 5,6 & 5,6 & 5 & 4,5 & 2 & 2,3 & 2,3 & 5,4 & 2,3 \\
\hline Burros Argentinos & 5,6 & 6,5 & 5,6 & 5,6 & 6,5 & $5, \overline{6}$ & 2,3 & 5 & 5,4 & 5 \\
\hline Mortiño & 1 & 4,5 & 1 & 1 & 5 & 5 & 5,6 & 5,4 & 5 & 5 \\
\hline Caballero & 5,6 & 5,6 & 5,6 & 5,6 & 6,5 & 5,6 & 4,5 & 5,4 & 4,5 & 4,5 \\
\hline Nuña Maní Roja & 1 & 4,3 & 1 & 2 & 2 & 3,4 & 5 & 5,4 & 5,4 & 5,4 \\
\hline Bolón Rojo & 5,6 & 5 & 5 & 5,4 & 5,6 & 5 & 5,4 & 5,4 & 5,4 & 4,5 \\
\hline Bolón Bayo & 5,6 & 6 & 5,6 & 5,6 & 5,6 & 5 & 5,4 & 5,4 & 4,5 & 5 \\
\hline
\end{tabular}

a Virulence ratings: $1=$ no symptoms, $2=$ necrotic reaction without sporulation, $3=$ uredinia $<300 \mu \mathrm{m}$ in diameter, $4=$ uredinia 300 to $500 \mu \mathrm{m}$ in diameter, $5=$ uredinia 500 to $800 \mu \mathrm{m}$ in diameter, $6=$ uredinia $>800 \mu \mathrm{m}$ in diameter.

${ }^{\mathrm{b}}$ Geographic origin of isolates: $\mathrm{ARG}=$ Argentina, $\mathrm{DR}=$ Dominican Republic, $\mathrm{HON}=$ Honduras, JA = Jamaica, USA = United States.

${ }^{c}$ The first 15 landraces listed are Middle American and the last 15 listed are Andean. 
exclusively of bands associated with nonspecific virulence (nonspecific isolates from the Dominican Republic, Honduras, Jamaica, and the United States); and a group of two intermediate isolates which had the majority of all bands from both groups (the Andean-specific isolate from the Dominican Republic and the nonspecific isolate from Argentina).

The relationships between the isolates and the three groups they form are illustrated in Figure 2. The figure is the result of parsimony analysis of the RAPD banding-pattern data, where the presence and absence of particular bands were used as characters. Although this analysis does not recover true evolutionary relationships, it does assume that evolution occurs and that similarity is the result of descent with modification. The analysis illustrates the degrees of similarity of the RAPD banding patterns, and further shows that the two intermediate isolates are not necessarily more similar to one another than to isolates of the other two groups.

\section{DISCUSSION}

The concept that isolates of $U$. appendiculatus exhibit group-specific virulence is not new. Races 38 and 39 were referred to as green bean isolates before it was clearly demonstrated that green bean germ plasm is primarily of Andean origin. It was the clear designation of host genotypes as Andean or Middle American that allowed the partitioning of bean rust isolates into ecologically meaningful groups.

Previously, Andean and Middle American specificity was investigated for the bean pathogens Colletotrichum lindemuthianum $(18,19)$ and Phaeoisariopsis griseola $(9,18)$. The conclusions from the C. lindemuthianum studies were similar to the conclusions made in this paper; two pathogen groups were defined based on RAPD data, some of the isolates were specific for Andean germ plasm, and no true Middle American specificity was found. The two studies using $P$. griseola also defined two pathogen groups using RAPD analysis, and also found one group

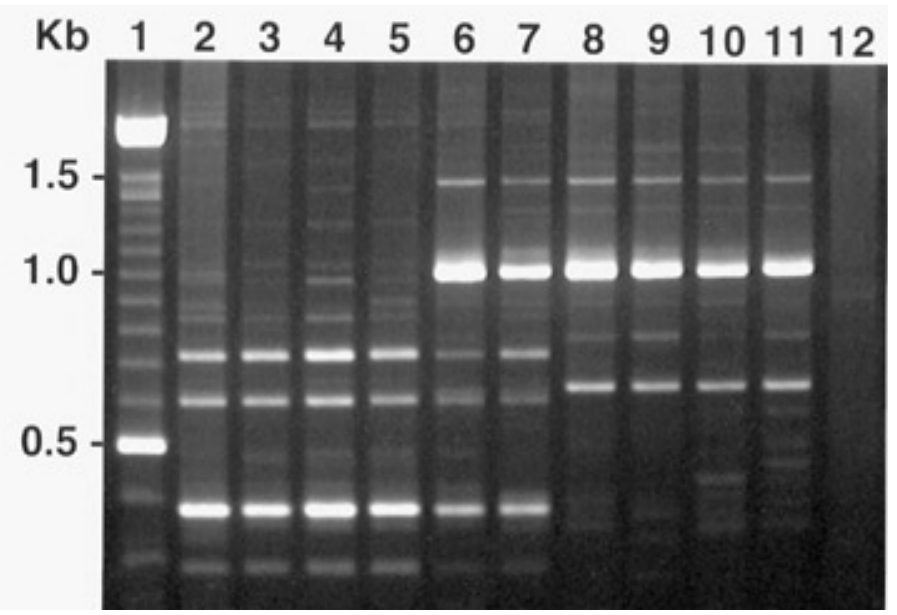

Fig. 1. Banding patterns produced by agarose-gel electrophoresis of products from random amplified polymorphic DNA analysis of isolates of Uromyces appendiculatus with Andean-specific virulence or nonspecific virulence. Lane 1 contains size markers in 100-kilobase pair increments; lanes 2 through 6 contain fragments amplified from Andean-specific isolates; lanes 7 through 11 contain fragments amplified from nonspecific isolates; and lane 12 contains a control reaction mixture to which no sample DNA was added. to be Andean specific. Using exclusively Latin American isolates, the study reported by Pastor-Corrales (18) did not detect specificity for Middle American germ plasm. Middle American specificity was found in the study by Guzmán et al. (9), who used Malawian lines or cultivars representing the Andean and Middle American gene pools to characterize the specificity of the $P$. griseola isolates from Brazil, Malawi, and the United States.

The three pathogens for which Andean specificity has been demonstrated are all highly variable and present a formidable challenge in developing stable host resistance. A better understanding of their specificity will aid in screening for new sources of resistance. The above-cited studies indicate that, for at least three specific pathogens, Middle American germ plasm offers the broadest spectrum of resistance genes, at least for the isolates tested. In the case of bean rust, a parallel study (2) supports our findings that the reaction of Middle American germplasm to populations of $U$. appendiculatus is more variable than that of the Andean material tested.

Several previous studies have characterized the diversity of $U$. appendiculatus using virulence $(16,25)$, isozyme analysis $(12,13,15)$, and DNA analysis $(5,14,16)$. Although some of these reports included discussion of Andean and Middle American specificity, none of them were specifically designed to demonstrate it. This study was uniquely designed for that purpose, in that isolates were chosen based on the specificity indicated by their disease reactions on the standard differentials, rather than on the gene pool of the host from which they were originally isolated; pairs of isolates were used to control for effects of geography; and the specificity of the virulence was confirmed by inoculation onto a set of Andean and Middle American landrace differentials.

Given the extent to which Andean and Middle American populations of $P$. vulgaris (wild and domesticated) differ from

Table 3. Frequency of random amplified polymorphic DNA (RAPD) banding patterns for a set of isolates of Uromyces appendiculatus with Andeanspecific or nonspecific virulence

\begin{tabular}{|c|c|c|c|c|c|c|c|c|c|c|c|}
\hline \multirow[b]{2}{*}{ Pattern } & \multirow[b]{2}{*}{ Frequency $^{\mathbf{b}}$} & \multicolumn{5}{|c|}{ Andean-specific isolates ${ }^{a}$} & \multicolumn{5}{|c|}{ Nonspecific isolates $^{a}$} \\
\hline & & ARG & HON & JA & USA & DR & ARG & HON & $\mathbf{J A}$ & USA & DR \\
\hline 1 & 21 & + & + & + & + & + & + & - & - & - & - \\
\hline 2 & 19 & - & - & - & - & + & + & + & + & + & + \\
\hline 3 & 1 & + & + & + & + & - & - & - & - & - & - \\
\hline 4 & 1 & - & + & + & + & + & - & - & - & - & - \\
\hline 5 & 1 & + & - & - & - & - & + & - & - & - & - \\
\hline 6 & 1 & - & - & - & - & - & + & + & + & + & + \\
\hline 7 & 2 & - & - & - & - & + & - & + & + & + & + \\
\hline 8 & 1 & - & - & - & - & - & - & + & + & + & + \\
\hline 9 & 1 & - & - & - & - & + & - & + & + & + & - \\
\hline 10 & 2 & - & - & - & - & - & - & - & - & + & + \\
\hline
\end{tabular}

${ }^{a}$ Isolates from five western hemisphere countries were classified as Andean-specific or nonspecific based on virulence tests on 30 landraces of Phaseolus vulgaris. Geographic origin of isolates: ARG = Argentina, DR $=$ Dominican Republic, HON = Honduras, JA = Jamaica, and USA $=$ United States of America. Presence of a band is indicated by a plus sign.

${ }^{\mathrm{b}}$ Number of polymorphic RAPD bands, out of a total of 50, that gave the indicated pattern. 
each other genetically and phenotypically, it is not surprising that specific virulences of its pathogens have evolved. The pathogenic variability of $U$. appendiculatus detected in Middle American isolates and the relative homogeneity of Andean isolates seem to reflect the morphologic (21) and biochemical $(7,21)$ differences found between those two bean gene pools.

While virulence patterns on the landrace differentials established the existence of Andean-specific pathotypes of $U$. appendiculatus, they are insufficient to determine if the Andean-specific isolates have a common genetic background. The data from the RAPD analysis, however, does demonstrate a common genetic background, which implies that the Andean specificity detected in this study has a single evolutionary origin. Without information on the resistances present in natural populations, it is impossible to determine when and where Andean-specific virulence arose. The movement of domesticated beans throughout the Americas by preColumbian peoples, followed by pandemic movement in the post-Colombian era (21), has blurred the distribution of the two bean populations and exposed germ plasm from both populations to various pathogen populations. It is reasonable to hypothesize that Andean-specific virulence arose in wild Andean populations before the domestication of $P$. vulgaris and that it spread throughout the world in post-Colombian times.

The common genetic background of the Andean-specific isolates used in this study does not preclude the possibility that the fungus has continued to evolve since arriving in other parts of the world. Variation in Australian populations of $U$. appendiculatus was attributed to evolution after its arrival on that continent $(5,18)$. Two groups, A and B, were found in Australia using RAPD analysis, neither of which corresponded to a third group, C, comprising isolates from the United States. The

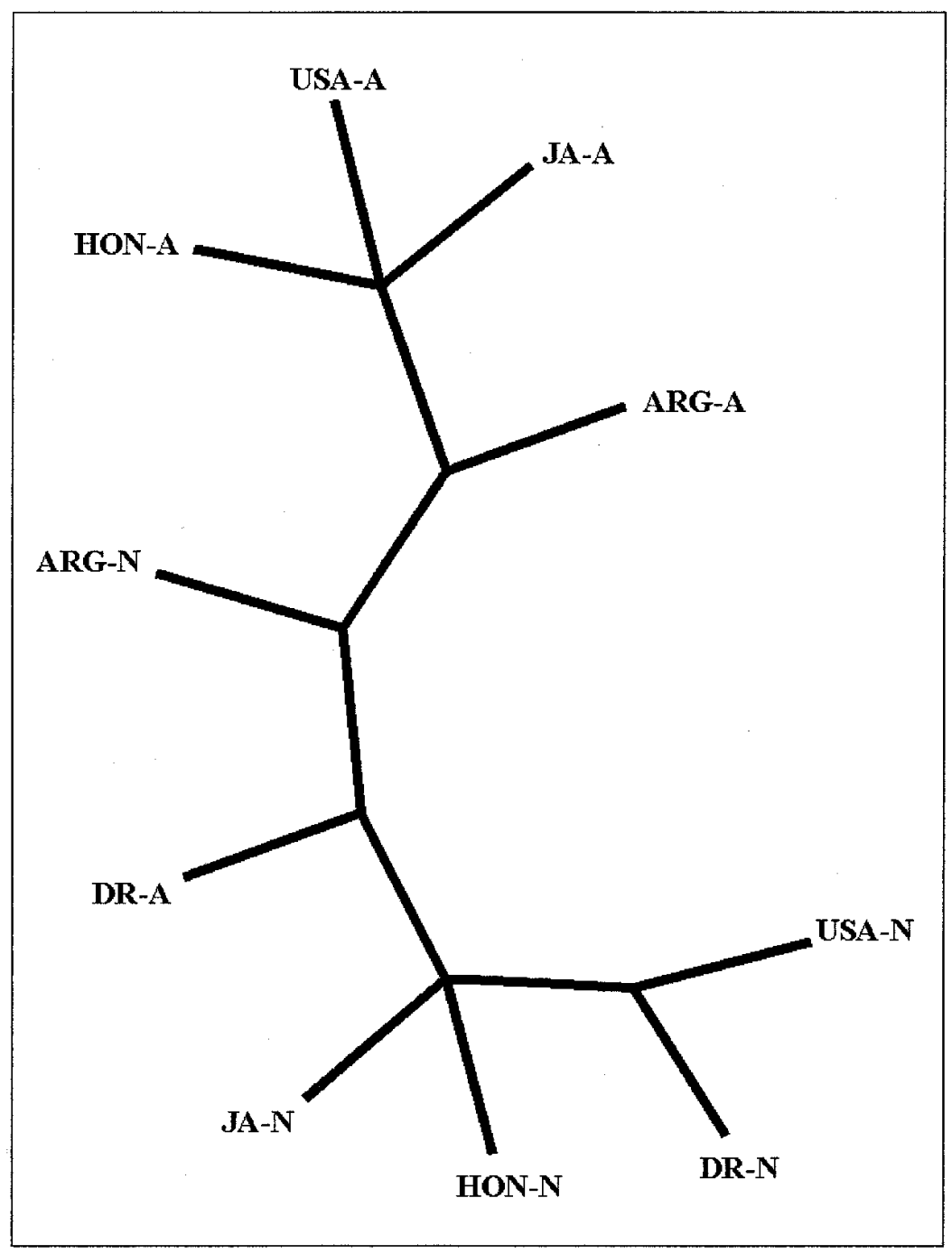

Fig. 2. Unrooted tree resulting from parsimony analysis of random amplified polymorphic DNA banding patterns from Andean-specific and nonspecific isolates of Uromyces appendiculatus. Geographic origin of the isolates were: $\mathrm{ARG}=$ Argentina, $\mathrm{DR}=$ Dominican Republic, $\mathrm{HON}=$ Honduras, $\mathrm{JA}=$ Jamaica, and USA = United States of America. Virulence specificity is indicated after the abbreviation for geographic origin; $\mathrm{A}=$ Andean-specific, $\mathrm{N}=$ nonspecific. authors suggested that groups $\mathrm{B}$ and $\mathrm{C}$ might be Andean and Middle American, respectively. Group A, they proposed, evolved out of $\mathrm{B}$ in the relative isolation of the Australian continent. Intermediate types were also found, apparently similar to isolates A-DR and M-ARG used in this study.

Three groups were also identified by Araya (2), who recently used RAPD banding patterns and phenotypic reaction of a set of bean rust differentials to characterize a large collection of isolates from Latin America. Those groups primarily consisted of isolates which were Andean, Middle American, and a mixture of the two. Therefore, the identification of groups associated with Andean or Middle American germ plasm is consistent, as is the identification of isolates which are genetically intermediate between the two groups.

The existence of intermediate types based on RAPD analysis indicates that isolates from the Andean-specific group and the nonspecific group are at least able to form dikaryons with each other. The apparent absence of recombination of RAPD bands suggests that such dikaryons are unable to complete the sexual cycle, including meiosis and independent segregation of RAPD primer sites.

\section{ACKNOWLEDGMENTS}

We thank D. O'Keefe and L. Sutton for their help with this work.

\section{LITERATURE CITED}

1. Abd-Alla, H. M., Stavely, J. R., Ouf, M. F., Gazar, A. A., Shihata, Z. A., and Liebenburg, M. M. 1996. New pathogenic variability in Uromyces appendiculatus from Egypt, Honduras, South Africa, and the United States. (Abstr.) APS/MSA Ann. Meet. Indianapolis, IN.

2. Araya, C. M. 1996. Pathogenic and molecular variability and telia production of Uromyces appendiculatus isolates from the Andean and Middle American centers of domestication of common bean. Ph.D. dissertation, University of Nebraska, Lincoln.

3. Balcita, M. A., and Hartmann, R. W. 1993. Pathogenic variability in Uromyces appendiculatus (Pers.) Unger var. appendiculatus in Hawaii. Ann. Rep. Bean Improv. Coop. 36:160-161.

4. Becerra Velásquez, V. L., and Gepts, P. 1994. RFLP diversity of common bean (Phaseolus vulgaris) in its centers of origin. Genome 37:256-263.

5. Braithwaite, K. S., Manners, J. M., Irwin, J. A. G., and Maclean, D. J. 1994. DNA markers reveal hybrids between two diverse background genotypes in Australian collections of the bean rust fungus Uromyces appendiculatus. Aust. J. Bot. 42:255-267.

6. Gepts, P., Osborn, T. C., Rashka, K., and Bliss, F. A. 1986. Phaseolin-protein variability in wild forms and landraces of the common bean (Phaseolus vulgaris): evidence for multiple centers of domestication. Econ. Bot. 40:451-468.

7. Gepts, P., Singh, S. P., Becerra Velasquez, V., Koinange, E. M. K., Sonnante, G., and Stockton, T. 1994. The genetics of domestication in common bean. Pages 25-35 in: Proc. Second Int. Sci. Meet. Phaseolus Beans Adv. Biotechnol. Res. Network. W. M. Roca, J. E. 
Maver, M. A. Pastor-Corrales, and J. Tohme, eds. CIAT. Cali, Colombia.

8. Grajal-Martin, M. J., Simon, C. J., and Muehlbauer, F. J. 1993. Use of random amplified polymorphic DNA (RAPD) to characterize race 2 of Fusarium oxysporum f. sp. pili. Phytopathology 93:612-614.

9. Guzmán, P., Gilbertson, R. L., Nodari, R., Jhonson, W. C., Temple, S. R., Mandala, D., Mkandawire, A. B. C., and Gepts, P. 1995. Characterization of variability in the fungus Phaeoisariopsis griseola suggests coevolution with the common bean (Phaseolus vulgaris). Phytopathology 85:600-607.

10. Haley, S. D., Miklas, P. N., Afanador, L., and Kelly, J. D. 1994. Random amplified polymorphic DNA (RAPD) marker variability between and within gene pools of common bean. J. Am. Soc. Hortic. Sci. 119:122-125.

11. Hamelin, R. C. 1996. Genetic diversity between and within cankers of the white pine blister rust. Phytopathology 86:875-879.

12. Linde, D. C., Groth, J. V., and Roelfs, A. P. 1990. Comparison of isozyme and virulence diversity patterns in the bean rust fungus Uromyces appendiculatus. Phytopathology 80:141-147.

13. Lu, T. H., and Groth, J. V. 1987. Isozyme detection and variation in Uromyces appendiculatus. Can. J. Bot. 66:885-890.

14. Maclean, D. J., Braithwaite, K. S., Irwin, J. A. G., Manners, J. M., and Groth, J. V. 1995. Random amplified polymorphic DNA reveals relationships among diverse genotypes in Australian and American collections of Uromyces appendiculatus. Phytopathology 85:757-765.

15. McCain, J. W., and Groth, J. V. 1992. Interand intrapopulation isozyme variation in collections from sexually reproducing populations of the bean rust fungus, Uromyces appendiculatus. Mycologia 84:329-340.

16. Meskine, M. 1994. Variability of bean rust pathogen, Uromyces appendiculatus, measured by virulence and random amplified polymorphic DNA analysis. Ph.D. dissertation, University of Nebraska, Lincoln.

17. Mmbaga, M. T., and Stavely, J. R. 1988. Pathogenic variability in Uromyces appendiculatus from Tanzania and rust resistance in Tanzanian bean cultivars. Plant Dis. 72:259262.

18. Pastor-Corrales, M. A. 1996. Traditional and molecular confirmation of the coevolution of beans and pathogens in Latin America. Ann. Rep. Bean Improv. Coop. 39:46-47.

19. Pastor-Corrales, M. A., Otoya, M. M.,
Molina, A., and Singh, S. P. 1995. Resistance to Colletotrichum lindemuthianum isolates from Middle America and Andean South America in different common bean races Plant Dis. 79:63-67.

20. Sandlin, C. M., and Steadman, J. R. 1994 Characterization of pathotypes of the bean rust fungus which overcome adult plant resistance. Ann. Rep. Bean Improv. Coop. 37:63-64.

21. Singh, S. P., Gepts, P, and Debouck, D. G 1991. Races of common bean (Phaseolus vulgaris L., Fabaceae). Econ. Bot. 45:379-396.

22. Stavely, J. R. 1984. Pathogenic specialization in $U$. phaseoli in the United States and rust resistance in beans. Plant Dis. 68:95-99.

23. Stavely, J. R., Freytag, G. F., Steadman, J. R. and Schwartz, H. F. 1983. The 1983 bean rust workshop. Ann. Rep. Bean Improv. Coop. 26:iv-vi.

24. Stavely, J. R., and Pastor-Corrales, M. A 1989. Rust. Pages 159-174 in: Bean Production Problems in the Tropics. H. F. Schwartz and M. A. Pastor-Corrales, eds. CIAT. Cali, Colombia.

25. Stavely, J. R., Steadman, J. R., and McMillan, R. T. 1989. New pathogenic variability in Uromyces appendiculatus in North America. Plant Dis. 73:428-432. 